\title{
KEMAMPUAN BERPIKIR PESERTA DIDIK PADA MATERI ALJABAR
}

\author{
Nandang Arif Saefuloh 1 , Wahyudin'2, Sufyani Prabawanto 3 , Usep Kosasih ${ }^{4}$ \\ 1,4 Universitas Islam Nusantara, Jl. Soekarno-Hatta No. 530, Bandung, Indonesia \\ 1,2,3 Universitas Pendidikan Indonesia, Jl. Setiabudi No. 229, Bandung, Indonesia \\ Email: narifsaefuloh@yahoo.com
}

\begin{abstract}
Two perceptions related to constructivism-based learning and behaviorism-based learning give rise to variations in the type of learning model with their respective arguments of advantages and disadvantages that directly affect the learning outcomes and thinking skills of students. This study aims to describe the thinking skills of students based on classifications from Hillocks and Shulman namely substantive, mechanical-syntactic, formal-rhetorical, and combine mechanical-formal. The research method used qualitative studied by analyzing the answers of students who have gone through basic algebraic learning using expository learning models. The results of the analysis obtained the findings of the thinking skill of students reviewed from the type of thinking skills, namely students using substantive and mechanicalsyntactic thinking skills in solving problems/problems given by educators, then the problem of initial knowledge (prior knowledge) arises in the stage of solving the problem of the learner, the absence (forget/not know) of the initial knowledge makes some of the problems given encounter the wrong results even though the learner uses one of the two thinking skills (substantive, mechanical-syntactic). The implications of the problem, the learner must be attempted to conduct a review (looking back) on the description of the answer he has worked on, by analyzing the answers from other knowledge (preliminary knowledge) that may be in the answer stage.
\end{abstract}

Keywords: Looking back, prior knowledge, thinking skills

\begin{abstract}
ABSTRAK
Dua persepsi terkait pembelajaran berbasis konstruktivisme dan pembelajaran berbasis behaviorisme melahirkan variasi pada jenis model pembelajaran dengan argumen kelebihan dan kekurangannya masing-masing yang berpengaruh secara langsung terhadap hasil belajar dan kemampuan berpikir peserta didik. Penelitian ini bertujuan untuk mendeskripsikan kemampuan berpikir peserta didik berdasarkan klasifikasi dari Hillocks dan Shulman yakni substantive, mechanical-syntactic, formal-rhetorical, dan combine mechanical-formal. Metode penelitian menggunakan studi kualitatif dengan menganalisis jawaban peserta didik yang telah melalui pembelajaran aljabar dasar dengan menggunakan model pembelajaran ekspositori. Hasil analisis diperoleh temuan kemampuan berpikir peserta didik yang ditinjau dari jenis kemampuan berpikir, yaitu peserta didik menggunakan kemampuan berpikir substantive dan mechanical-syntactic dalam menyelesaikan masalah/soal yang diberikan oleh pendidik, kemudian permasalahan pengetahuan awal (prior knowledge) muncul dalam tahapan penyelesaian soal peserta didik, ketiadaan (lupa/tidak tahu) pengetahuan awal menjadikan beberapa soal yang diberikan menemui hasil yang keliru meskipun peserta didik menggunakan salah satu dari dua kemampuan berpikir tersebut (substantive, mechanical-syntactic). Implikasi dari masalah tersebut, peserta didik harus diupayakan melakukan peninjauan ulang (looking back) atas uraian jawaban yang telah dia kerjakan, dengan menganalisis jawaban dari pengetahuan lain (pengetahuan awal) yang mungkin ada dalam tahapan jawabannya.
\end{abstract}

Kata kunci: Kemampuan berpikir, looking back, pengetahuan awal

Dikirim: 9 Juli 2020; Diterima: 25 Agustus 2020; Dipublikasikan: 30 September 2020

Cara sitasi: Saefuloh, N. A., Wahyudin, Prabawanto, S., \& Kosasih, U. (2020). Kemampuan berpikir peserta didik pada materi aljabar. Teorema: Teori dan Riset Matematika, 5(2), 203-210. 


\section{PENDAHULUAN}

Aliran konstruktivisme menjadi populer bagi model pembelajaran saat ini, indikasinya terlihat dari digunakannya problem-based learning, project-based learning, dan discovery learning (PBL, PjBL, DL) sebagai model pembelajaran baku dalam implementasi kurikulum nasional. Aliran ini meyakini bahwa pengetahuan diperoleh jika manusia mengkonstruksi pengetahuan secara mandin. Seperti halnya dinyatakan oleh Geary (Schunk, 2012: 323) tentang asumsi utama dari konstruktivisme, bahwa manusia merupakan peserta didik aktif yang mengembangkan pengetahuan bagi diri mereka sendiri. Lebih jauh, landasan filosofi matematika menurut Ernest (1991: 42) dikategorikan sebagai konstruktivisme sosial, hal ini dapat dijelaskan oleh tiga hal berikut yang saling berkaitan: (1) basis pengetahuan matematika adalah pengetahuan bahasa, kesepakatan-kesepakatan, dan aturan-aturan, yang merupakan suatu konstruktivisme sosial; (2) proses sosial di dalam individu dibutuhkan untuk merubah pengetahuan matematis subjektif individu, setelah publikasi, kepada pengetahuan matematis objektif yang diterima; dan (3) objektivitas itu sendin akan dipahami sebagai sosial. Pemahaman Ernest sangat masuk akal, dimana suatu pengetahuan tentu tidak lepas dari kehidupan sosial manusia, begitulah matematika, di dalamnya berisi bahasa, kesepakatan-kesepakatan, dan aturan-aturan yang secara langsung merupakan proses konstruksi sosial. Sehingga wajarlah jika Ernest (1991: 11) menyatakan lebih jauh, bahwa menurut kalangan konstruktivisme, pembelajaran matematika konvensional tidak aman dan perlu diubah dengan metode konstruktif, pengetahuan harus diperkuat melalui pembuktian konstruktif, didasarkan pada penalaran konstruktivis yang dibatasi, dan pengertian objek-objek matematika terdiri dari prosedur formal yang dikonstruksi.

Di lain pihak, dalam penelitian yang terkait implementasi pembelajaran berbasis konstruktivisme, Saefuloh et al. (2020: 31), menyatakan bahwa "Tidak terdapat peningkatan hasil belajar yang signifikan, peserta didik yang belajar dengan pembelajaran konflik kognitif pendekatan PBL". Temuan ini tentu saja merupakan satu contoh kasus yang mencoba menampilkan fakta di lapangan terkait implementasi pembelajaran berbasis konstruktivisme yang hasilnya tidak sebaik dari yang diungkapkan secara teoritis. Kemudian, faktor lain terkait ketidaksiapan peserta didik tentang prasyarat materi pembelajaran dalam hal konstruksi pengetahuan, yaitu tidak adanya pengetahuan/ide awal yang dimiliki peserta didik untuk menjembatani penerimaan ide baru. Menurut Van de Walle (2008: 57) bahwa pengkonstruksian ide baru terjadi melalui konstruksi ide-ide lama dengan ide-ide baru. Hal ini senada dengan pemikiran Kirschner et al. (2006) tentang kelemahan pada model pembelajaran berbasis konstruktivisme, yang disebutnya sebagai model pembelajaran dengan bimbingan minimum, menyebutkan bahwa pembelajaran dengan bimbingan minimum memberatkan memori kerja (working memory) peserta didik sehingga efektivitas dan efisiensinya rendah yang besar kemungkinan dapat menyebabkan gagalnya informasi/pengetahuan tersimpan dalam ingatan jangka panjang (long term memory). Selanjutnya, dalam artikel yang berjudul "What Human Cognitive Architecture Tells Us About Constructivism", Sweller (2009) menyatakan bahwa arsitektur kognitif manusia secara alami tidak sesuai dengan pembelajaran berbasis konstruktivisme yang meminta pembelajaran untuk membiarkan peserta didik membangun pengetahuan materi secara mandiri melalui permasalahan yang diberikan oleh guru. Sebaliknya arsitektur kognitif manusia lebih sesuai dengan pembelajaran langsung (direct learning) yang secara langsung memberitahukan informasi penting (pengetahuan) yang dibutuhkan oleh peserta didik dalam memecahkan masalah.

Dua kutub persepsi di atas (pembelajaran berbasis konstruktivisme dan pembelajaran berbasis behaviorisme) menjadi topik perdebatan hangat di kalangan peneliti maupun praktisi pendidikan dengan masing-masing argumennya. Hal ini berdampak secara langsung pada pengelolaan kelas yang dilakukan oleh seorang guru sebagai praktisi pendidikan dalam proses pembelajaran. Pembuatan rencana pelaksanaan pembelajaran (RPP) yang didalamnya terkandung model pembelajaran yang akan digunakan menjadi media bagi seorang guru dalam menambatkan keyakinan teori belajar pembelajaran yang dianutnya pada praktek di kelas. Sehingga dari perbedaan tersebut melahirkan persepsi yang beragam dari peserta didik dalam memaknai materi dan membangun pengetahuan yang disampaikan oleh guru melalui model pembelajaran yang dipakainya. Selanjutnya, dari persepsi yang telah dialami oleh peserta didik akan dilanjutkan dengan proses berpikir. Adapun proses berpikir menurut Piaget (Clauss, et 
al., 2010: 209) ditempuh melalui beberapa tahapan, diantaranya: (1) asimilasi, yaitu proses menerjemahkan informasi yang masuk ke dalam bentuk yang dapat dipahami; (2) akomodasi, yaitu proses mengadaptasi struktur pengetahuan saat ini dalam menanggapi pengalaman baru; dan (3) equilibration, yaitu proses menyeimbangkan asimilasi dan akomodasi untuk menciptakan pemahaman yang stabil. Selanjutnya, Hamilton \& Ghatala (1994: 92-94) mengulas tentang kemampuan berpikir oleh peserta didik yang dipengaruhi oleh persepsi peserta didik terhadap materi pelajaran, dimana persepsi adalah proses yang memilih dan mengenali sinyal-sinyal fisik yang merangsang indera. Kemudian, persepsi membangun sebuah interpretasi dari stimulan lingkungan dengan menggunakan pengetahuan ke dalam skema yang telah dimiliki. Eksplorasi persepsi yang penting dalam input processing setelah melalui suatu proses pembelajaran menjadi sebuah kasus yang menarik untuk ditelaah. Menurut Hillocks \& Shulman (1999) berdasarkan jenis pengetahuannya, terdapat 4 jenis kemampuan berpikir yaitu substantive, mechanical-syntactic, formal-rhetorical, dan combine mechanical-formal. Hillocks \& Shulman tidak menjelaskan apakah keempat pengetahuan ini memiliki tingkatan atau tidak. Meskipun demikian, kita dapat melihat bahwa pengetahuan substantive dan mechanical-syntactic merupakan kondisi yang berlainan. Artinya tidak dapat memiliki urutan satu sama lainnya.

Bedasarkan latar belakang di atas tujuan dari penelitian ini adalah mendeskripsikan kemampuan berpikir peserta didik pada materi aljabar dasar dalam model pembelajaran ekspositori yang senada dengan paradigma pembelajaran behaviorisme, dari hasil deskripsi melalui perbandingan temuan fakta di lapangan dengan teori acuan dapat menjadi penguat atau menjadi koreksi teori sebelumnya sehingga dapat menjadi teori baru dalam hirarki keilmuan.

\section{METODE PENELITIAN}

Penelitian ini bertujuan untuk memahami bagaimana kemampuan berpikir peserta didik pada materi aljabar dalam model pembelajaran ekspositori. Berdasarkan tujuan ini, penelitian ini dilakukan dengan pendekatan penelitian kualitatif, dengan desain studi kasus untuk memperoleh deskripsi spesifik dari objek yang diteliti yang dalam prosesnya memerlukan kajian mendalam dari peristiwa-peristiwa nyata di lapangan. Fraenkel et al. (2012: 426) menyatakan bahwa "Studi penelitian yang menyelidiki kualitas hubungan, aktivitas, situasi, atau materi sering disebut sebagai penelitian kualitatif'. Kemudian, Teppo (1998) menyebutkan bahwa "Penelitian kualitatif berfokus pada proses, makna, dan sifat realitas yang dibentuk secara sosial dan memberikan wawasan tentang fenomena yang sedang dipelajari yang tidak dapat diperoleh dengan cara lain".

Sebanyak sembilan peserta didik kelas delapan menjadi sampel yang terdiri dari empat pria dan lima wanita yang berasal dari salah satu Sekolah Menengah Pertama (SMP) di Kota Bandung yang telah dipilih secara purposif. Pengumpulan data dilakukan dengan memberikan soal formatif sebanyak 10 butir soal aljabar yang harus dipecahkan dalam sebuah pembelajaran. Pekerjaan peserta didik dalam menjawab masalah yang disajikan dalam penelitian dianalisis dengan coding dan teknik perbandingan konstan (Lacey \& Luff, 2001), yang dilakukan oleh para peneliti dan guru ahli sekolah. Beberapa kasus yang mewakili hasil analisis, selanjutnya divalidasi dengan melakukan wawancara dalam bentuk konfirmasi kepada peserta didik.

\section{HASIL DAN PEMBAHASAN}

Kemampuan berpikir merupakan bagian dari proses metakognisi. Metakognisi merupakan segala aktivitas yang mengatur kognisi. Menurut Flavell (Schunk, 2012) bahwa metakognisi memiliki makna intinya adalah kognisi mengenai kognisi. Salah satu kemampuan berpikir yang dapat kita amati dalam metakognisi antara lain bagaimana langkah-langkah yang dilakukan dalam berpikir. Dalam hal ini peserta didik perlu memiliki kemampuan metakognisi untuk melakukan prediksi, perencanaan, pemantauan dan evaluasi terhadap proses penyelesaian masalah (Zakiah, 2016). Menurut Hillocks \& Shulman (1999) berdasarkan jenis pengetahuannya, terdapat 4 jenis kemampuan berpikir yakni substantive, mechanicalsyntactic, formal-rhetorical, dan combine mechanical-formal. Deskripsi kemampuan berpikir peserta didik dalam menyelesaikan masalah disajikan dalam Tabel 1. 
Tabel 1. Kemampuan berpikir peserta didik dalam menyelesaikan masalah

\begin{tabular}{ll}
\hline \multicolumn{1}{c}{ Kemampuan berpikir } & \multicolumn{1}{c}{ Dekripsi } \\
\hline Substantive & Mengetahui informasi dan cara penyelesaian yang tepat tanpa harus mengikuti pola \\
& penyelesaian umum. \\
Mechanical-syntactic & Menggunakan cara-cara penyelesaian yang dicontohkan pendidik, termasuk pola umum \\
& pemecahan masalah. \\
Formal-rhetorical & Mengidentifikasi contoh dan non-contoh pengetahuan, menamai pengetahuan dan sifat- \\
& sifat yang mendefinisikannya, memberikan definisi pada pengetahuan, dan \\
& mengkhususkan sifat-sifat yang membedakan pengetahuan dari hal lain yang berkaitan. \\
Combine mechanical-formal & Kombinasi berpikir mechanical-syntactic dan formal-rhetorical. \\
\hline
\end{tabular}

Hasil analisis yang diperoleh melalui penelaahan terhadap jawaban peserta didik dengan triangulasi melalui interview terhadap peserta didik, kemudian dilakukan perbandingan terhadap teori Hillocks \& Shulman (1999) yang dijadikan acuan. Hasil analisis menunjukkan terdapat dua kemampuan berpikir yang digunakan peserta didik dalam menyelesaikan masalah yang diajukan. Kemampuan berpikir tersebut adalah substantive dan mechanical-syntactic. Tidak ditemukan jawaban yang dapat dikategorikan pada tahap kemampuan berpikir formal. Oleh karena itu, tidak ditemukan pula kemampuan berpikir peserta didik yang tergolong pada kategori kombinasi mechanical-syntactic dan formal-rhetorical.

\section{a. Berpikir Substantive}

Kemampuan berpikir substantive terlihat pada jawaban soal nomor 1, 6, dan 10 yaitu soal menentukan solusi dari persamaan linier satu variabel, menggambar grafik fungsi kuadrat, serta fungsi pecah. Untuk menyelesaikan soal nomor 1 , menentukan nilai $x$ yang memenuhi persamaan linier satu variabel. Peserta didik dapat menggunakan pengetahuan operasi aljabar pada sebuah persamaan sesuai dengan materi yang diajarkan. Meskipun demikian, cara ini tidak digunakan oleh sebagian peserta didik. Peserta didik lebih memilih cara lain yang lebih mereka kenal untuk menyelesaikannya.

Untuk menyelesaikan soal nomor 1, kebanyakan peserta didik menggunakan cara yang disebut "pindah ruas". Meskipun jawaban yang disajikan tidak semua siswa memenuhi solusi yang benar, tetapi penggunaan cara "pindah ruas" dapat membantu proses pencapaian solusi. Kegagalan memperoleh solusi yang benar dikarenakan peserta didik keliru dalam menerapkan sifat distributif perkalian terhadap penjumlahan, $a \times(b+c)=(a \times b)+(a \times c)$ (Wahyudin, 2001: 95).

Salah satu contoh penyelesaian soal nomor 1 terlihat pada Gambar 1.

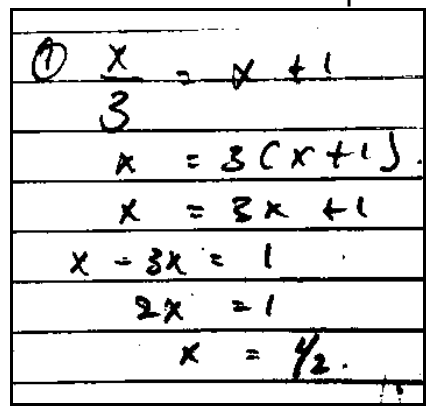

Gambar 1. Salah satu jawaban soal nomor 1

Pada Gambar 1 terlihat peserta didik menggunakan metode pindah ruas namun keliru saat menggunakan sifat distributif. Metode "pindah ruas" merupakan salah satu pengetahuan yang telah dikenalkan sejak tingkat dasar. Pengetahuan ini juga sering disinggung pada beberapa materi seperti geometri, kalkulus, dan sebagainya. Pada beberapa topik, pengetahuan ini dapat menjadi prasyarat. Demikian pula pada pengetahuan persamaan linier satu variabel, metode "pindah ruas" menjadi salah satu pengetahuan yang sering digunakan. Oleh karena itu pengetahuan ini sudah akrab bagi peserta didik. Di lain pihak, nyatanya metode ini tidak dapat diperumum sehingga bisa digunakan untuk soal pertidaksamaan, karena ada aturan tambahan jika kedua ruas dikali bilangan negatif maka tanda ketaksamaan harus diubah menjadi kondisi sebaliknya. Contoh kasus tersebut menjadi salah satu contoh kasus generalisasi yang berlebihan (overgeneralization) sehingga berpotensi pada miskonsepsi peserta didik terhadap materi pelajaran (Pinter et al., 2017: 11). 
Dalam penyelesaian soal nomor 1 , metode "pindah ruas" menjadi salah satu pengetahuan deklaratif dan prosedural. Peserta didik telah memiliki pengetahuan yang baik mengenai penerapan sifat distributif. Ini berarti peserta didik telah mencapai pengetahuan prosedural, yakni tahu bagaimana penerapan pengetahuan tersebut. Peserta didik juga memahami bahwa pengetahuan ini relevan untuk digunakan. Pada tahap ini, peserta didik sudah mencapai pengetahuan kondisional.

Peserta didik memiliki kesadaran tentang masalah yang disajikan. Pada sisi lain peserta didik juga menguasai metode "pindah ruas" sebagai pengetahuan prasyarat. Koneksi antara masalah yang disajikan dengan prasyarat yang relevan atau pengetahuan kondisional, mengarahkan peserta didik untuk memilih menyelesaikan masalah tanpa menggunakan prosedur yang dicontohkan. Proses ini menunjukkan bahwa peserta didik menggunakan cara pemikiran yang substantive dalam menyelesaikan soal nomor 1.

Proses pemikiran yang sama juga terlihat pada jawaban soal lainnya. Hasil analisis menyimpulkan bahwa peserta didik menggunakan kemampuan berpikir secara substantive pada jawaban soal nomor 1, 6, dan 10 yang telah diuraikan. Jawaban dari soal-soal tersebut, diketahui bahwa peserta didik memberikan jawaban tanpa menirukan langkah-langkah penyelesaian yang disajikan sumber belajar. Peserta didik lebih memilih cara penyelesaian yang sudah lama dipahaminya. Pengetahuan prasyarat yang tersimpan dalam memori jangka panjang (long term memory) menjadi aktif setelah terlibat koneksi dengan masalah yang disajikan (Schunk, 2012).

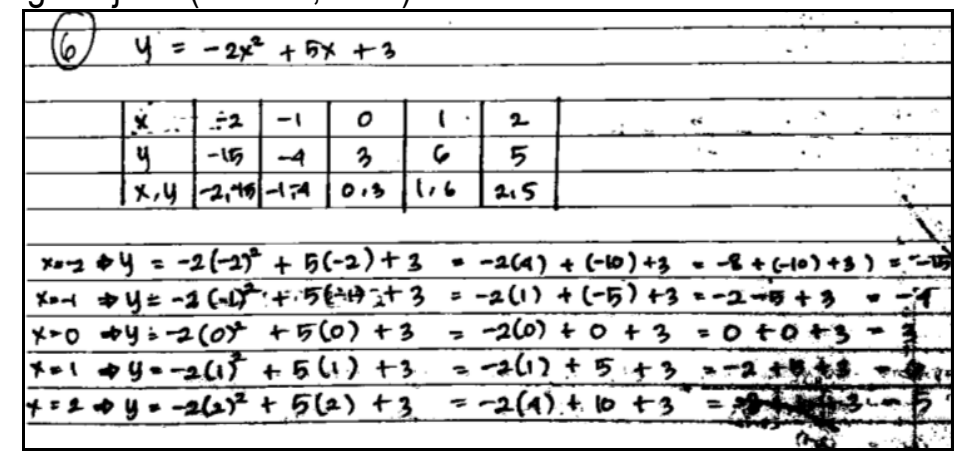

Gambar 2. Salah satu jawaban soal nomor 6

Pada Gambar 2 terlihat peserta didik menggunakan metode tabulasi untuk menggambar grafik fungsi kuadrat, tanpa menggunakan langkah-langkah yang diberikan pada sumber belajar yaitu: (1) menentukan titik potong sumbu- $x$ dan sumbu-y; dan (2) menentukan titik puncak. Hal ini terjadi lagi saat menyelesaikan soal nomor 10 , dimana peserta didik menggunakan metode tabulasi dalam menggambar grafik fungsi pecah. Lebih jauh, pembuatan dan interpretasi grafik yang akan dibuat sebaiknya didasarkan pada pemahaman konsep variabel (Khalil et al., 2019: 428). Pada persamaan yang akan dibuat grafiknya, seperti prosedur menggambar dengan proses menentukan titik potong sumbu- $x$ dan sumbu-y, lalu menentukan titik puncaknya, akan lebih mudah dipahami dan diingat oleh peserta didik.

Hasil analisis menemukan fakta bahwa terdapat beberapa keseragaman soal yang dijawab secara substantive. Pada penelitian ini, soal yang dijawab secara substantive adalah nomor 1, 6, dan 10. Hasil penelusuran diperoleh keseragaman pada soal nomor 1, 6, dan 10 tersebut. Masalah yang disajikan soal-soal tersebut memungkinkan penggunaan pengetahuan persamaan linier satu variabel dan pengetahuan menggambar grafik fungsi sebagai salah satu proses penyelesaiannya. Setiap jawaban yang disajikan peserta didik terhadap soal-soal tersebut, selalu menerapkan metode pindah ruas untuk soal nomor 1 dan metode tabulasi untuk soal nomor 6 dan 10 dalam penyelesaiannya.

Selanjutnya dilakukan wawancara untuk mengkonfiirmasi tentang penerapan metode pindah ruas untuk soal nomor 1 dan metode tabulasi untuk soal nomor 6 dan 10. Hasil transkrip wawancara terhadap beberapa partisipan disajikan berikut.

Transkrip wawancara 1

Interviewer : "Bagaimana cara Anda menjawab soal nomor 1?".

Responden : "Dengan cara kali silang dan pindah ruas Pak".

Interviewer : "Kenapa tidak menggunakan cara yang telah dipelajari dari sumber belajar?".

Responden : "Lama Pak". 


\section{Transkrip wawancara 2}

Interviewer : "Bagaimana cara Anda menjawab soal nomor 6 dan nomor 10?".

Responden : "Dengan cara substitusi Pak (tabulasi)".

Interviewer : "Kenapa tidak menggunakan cara yang telah dipelajari dari sumber belajar?".

Responden : "Lupa Pak".

Dari uraian wawancara yang disajikan di atas, nampak alasan peserta didik menggunakan pengetahuannya sendiri (berbeda dengan sumber belajar) dikarenakan cara yang bersangkutan lebih cepat (soal nomor 1) dan dengan alasan lupa (soal nomor 6 dan 10).

\section{b. Berpikir Mechanical-Syntactic}

Jawaban yang mengarah pada kemampuan berpikir secara mechanical-syntactic lebih banyak ditemukan pada penelitian ini dibanding kemampuan berpikir substantive dengan perbandingan 3 banding 2. Banyak jawaban yang menggunakan langkah-langkah penyelesaian persis dengan sumber belajar. Bahkan langkah-langkah penyelesaian menjadi acuan jawaban yang dihasilkan. Hasil analisis terhadap jawaban peserta didik ditemukan bahwa jawaban yang mengalami kesalahan proses perbandingan yang tidak tepat. Mereka mengupayakan menjawab sesuai langkah-langkah pada sumber yang dipelajari. Langkah-langkah seperti ini menjadi landasan peserta didik dalam menjawab. Hampir seluruh peserta didik menyajikan jawaban dengan langkah-langkah yang sama. Berikut beberapa contoh jawaban peserta didik yang mengarah pada kemampuan berpikir secara mechanical-syntactic, seperti disajikan pada Gambar 3 dan Gambar 4.

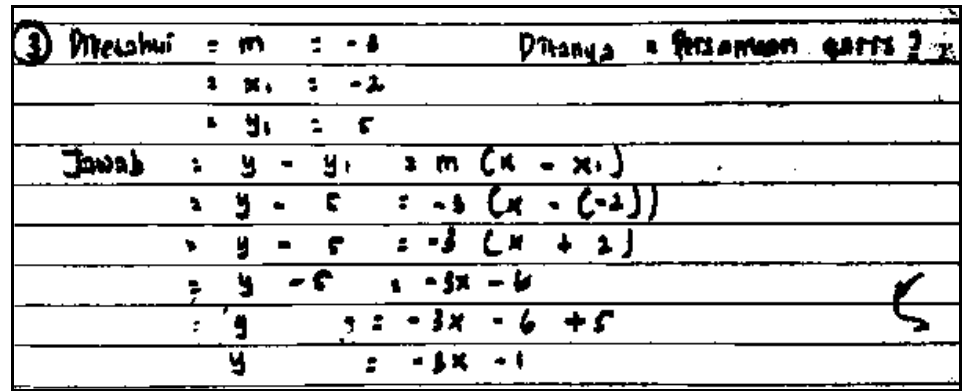

Gambar 3. Salah satu jawaban soal nomor 3

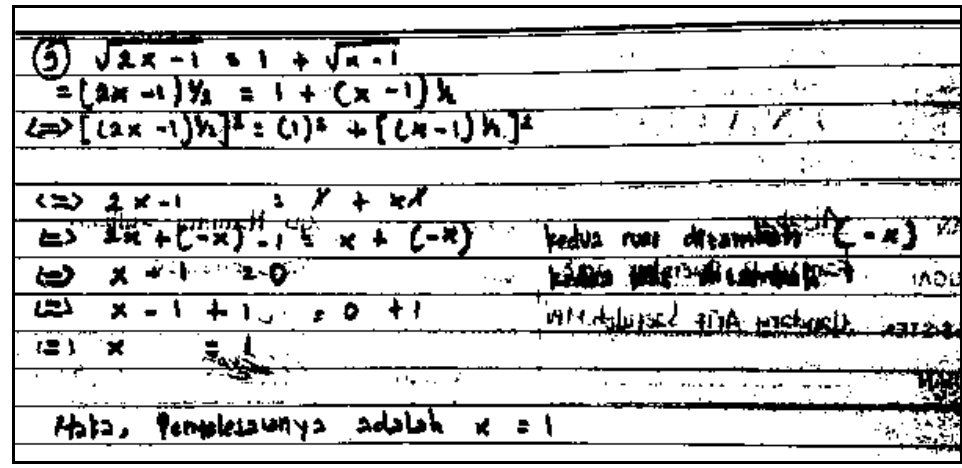

Gambar 4. Salah satu jawaban soal nomor 9

Pada Gambar 3 terlihat peserta didik menggunakan pengetahuan menyusun persamaan garis yang diketahui gradien dan satu titik yang dilalui garis tersebut, sama dengan langkah-langkah yang telah dipelajari dari sumber belajar. Demikian pula hal yang sama terlihat pada Gambar 4, peserta didik menggunakan pengetahuan menentukan nilai $x$ yang memenuhi persamaan irasional. Sama dengan langkah-langkah yang telah dipelajari dari sumber belajar, walau ternyata peserta didik melakukan kesalahan pada saat operasi perpangkatan bentuk aljabar dua suku, dan hal ini terjadi pada lebih dari satu partisipan. Peserta didik meyakini kebenaran jawaban karena merasa penyelesaian telah sesuai dengan cara yang dicontohkan. Pengulangan proses yang salah ini menunjukkan bahwa peserta didik tidak melakukan penelaahan jawaban secara substansi. Artinya pula bahwa peserta didik belajar tentang langkah-langkah tertentu yang dikenalkan sumber belajar bukan belajar tentang pengetahuan yang 
disajikan. Peserta didik memahami materi sebagai penyelesaian yang diajarkan. Hasil belajar dianggap sebagai kemampuan menerapkan proses penyelesaian soal yang diberikan. Langkah-langkah penyelesaian menjadi bagian yang diingat daripada bagaimana pengetahuan itu sebenarnya. Langkahlangkah penyelesaian seolah menjadi senjata untuk setiap soal pada materi yang sama, jawaban pada soal lainnya menunjukkan proses yang seragam. Ini menunjukkan kemampuan berpikir yang mechanicalsyntactic (Hillocks \& Shulman, 1999).

Pada saat wawancara dikonfirmasi mengenai hal ini (kekeliruan pada tahap perpangkatan bentuk aljabar dua suku), hasil transkrip wawancara disajikan berikut.

Transkrip wawancara:

Interviewer : "Kenapa jawaban Anda seperti ini?".

Responden : "Sama seperti contoh Pak, dikuadratkan kedua ruas".

Interviewer : "Tahukan Anda tentang perpangkatan bentuk aljabar dua suku".

Responden : "Oh iya Pak, lupa".

Dari uraian wawancara yang disajikan di atas, nampak alasan peserta didik adalah lupa pada pengetahuan perpangkatan bentuk aljabar dua suku yang menjadi prasyarat pada penyelesaian soal tersebut (persamaan bentuk irasional). Dalam kasus ini, peserta didik tidak dapat menerapkan pengetahuan yang telah dimilikinya kepada permasalahan yang ada. Hal ini dapat berarti siswa tersebut hanya dapat memahami pengetahuan pada konteks yang dicontohkan, tidak pada konteks yang lain. Tingkatan berpikir siswa baru pada tingkatan visual merujuk pada tiga tingkatan berpikir menurut Fyhn (2008), sehingga salah satu jembatan yang menghubungkan masalah dengan struktur kognisi adalah pengetahuan prasyarat (prior knowledge). Ketidakberadaan pengetahuan prasyarat dapat memastikan tidak akan terjadinya proses adaptasi pada kognisi. Kondisi yang memaksa peserta didik untuk menjawab soal yang diajukan, mendorong peserta didik untuk melakukan langkah-langkah yang tersedia dalam ingatannya. Sebagai implikasi dari tidak terdapatnya adaptasi, maka jawaban mekanistis yang menjadi pilihan untuk disajikan.

Hasil analisis diperoleh bahwa peserta didik mengalami banyak kekurangan dalam penguasaan pengetahuan prasyarat. Kondisi ini mengarahkan kemampuan berpikir peserta didik untuk berpikir secara mechanical-syntactic.

\section{KESIMPULAN}

Dari hasil analisis dapat disimpulkan kemampuan berpikir peserta didik yang ditinjau dari jenis kemampuan berpikir, peserta didik menggunakan kemampuan berpikir substantive dan mechanicalsyntactic dalam menyelesaikan masalah/soal yang diberikan oleh pendidik. Kemudian permasalahan prior knowledge muncul dalam tahapan penyelesaian soal peserta didik, ketiadaan (lupa/tidak tahu) pengetahuan awal menjadikan beberapa soal menemui hasil yang keliru meskipun peserta didik menggunakan salah satu dari dua kemampuan berpikir tersebut (substantive dan mechanical-syntactic).

\section{REKOMENDASI}

Implikasi dari masalah tersebut, peserta didik harus diupayakan melakukan peninjauan ulang/looking back atas uraian jawaban yang telah dia kerjakan, dengan menganalisis jawaban dari pengetahuan lain (pengetahuan awal) yang mungkin ada dalam tahapan jawabannya.

\section{DAFTAR PUSTAKA}

Clauss, E. C., S. et. al. (2010). Encyclopedia of cross-cultural school psychology. New York: Springer Science \& Business Media.

Ernest, P. (1991). The philosophy of mathematics education. London: Routledge Falmer.

Fraenkel, J. R, Wallen, N., \& Hyun, H. (2012). How to design and evaluate research in education. New York: McGraw-Hill. 
Fyhn, A. B. (2008). A climbing class' reinvention of angles. Educational Studies in Mathematics, 67(1), pp. 19-35. Springer.

Hamilton, R., \& Ghatala, E. (1994). Learning and instruction. New York: McGraw-Hill, Inc.

Hillocks, G., J., \& Shulman. (1999). Ways of thinking, ways of teaching. London: Teacher College Press.

Khalil, M., et al. (2019). Geogebra as a scaffolding tool for exploring analytic geometry structure and developing mathematical. International Electronic Journal of Mathematics Education, 14(2).

Kirschner, P. A., Sweller, J., \& Clark, R. E. (2006). Why minimal guidance during instruction does not work: An analysis of the failure of constructivist, discovery, problem-based, experiential, and inquiry-based teaching. Educational Psychologist, 41(2), 75-86.

Lacey, A., \& Luff, D. (2001). Trent focus for research and development in primary health care: An introduction to qualitative analysis. Trent Focus.

Pinter, H., H., et.al. (2017). The importance of structure, clarity, representation, and language in elementary mathematics instruction. Investigation in Mathematic Learning, 10.

Saefuloh, N. A., Kartasasmita, B. G., \& Kosasih, U. (2020). Meningkatkan kemampuan pemecahan masalah matematis peserta didik smp melalui strategi konflik kognitif pendekatan problembased learning (pbl) dengan sikap peserta didik sebagai variabel intervening. UJMES (Uninus Journal of Mathematics Education and Science), 5(1), 022-032.

Schunk D., H. (2012). Learning theories an educational perspective. Boston: Pearson Education, Inc.

Sweller, J. (2009). What human cognitive architecture tells us about constructivism. Constructivist Instruction: Success or Failure?. P. 127-143. New York: Routledge. 270 Madison Ave.

Teppo, A. R. (1998). Diverse ways of knowing. Qualitative Research Methods in Mathematics Education. Journal for Research in Mathematics Education. Monograph; no. 9.

Van de Walle, J. A. (2008). Matematika sekolah dasar dan menengah. Jakarta: Erlangga.

Wahyudin. (2001). Matematika SLTP. Bandung: Epsilon Grup.

Zakiah, N. E. (2016). Meningkatkan kemampuan metakognitif siswa melalui pembelajaran dengan pendekatan open-ended. Teorema: Teori dan Riset Matematika, 1(1). 